ENERGETICS

ЕНЕРГЕТИКА

UDC 662.997+697.7

V. Wysochin, PhD, Assoc. Prof.,

V. Nikulshin, DSc, Prof.,

A. Denysova, DSc, Prof.

Odessa Polytechnic State University, 1 Shevchenko Ave., Odessa, Ukraine, 65044; e-mail: vvwin.od@gmail.com

\title{
FACTORS OF THE PVT-COLLECTOR EFFICIENCY FORMATION
}

В.В. Височин, В.Р. Нікульшин, А.С. Денисова. Фактори формування ефективності РVT-колектора. Проведено аналітичні дослідження гібридного сонячного колектора (PVT) при виробництві електричної й теплової енергії. Математична модель, що прийнята, дозволяє проаналізувати характеристики РVT-колектора - температуру нагрівання абсорбера й охолодної рідини, а також продуктивність залежно від зовнішніх і режимних умов роботи пристрою. Мета роботи - розробка методу розрахунку експлуатаційних характеристик і визначення раціональних експлуатаційних режимів роботи гібридного сонячного колектора 3 урахуванням ефективної продуктивності. Використано комплексну математичну модель локального аналізу процесів теплообміну й електрогенерації гібридного сонячного колектора для реальних умов динамічної сонячної й кліматичної ситуації. Проведений аналіз теплообміну у варіантних умовах показав, що ефективність передачі тепла в системі охолодження колектора $\eta_{T}$, інакше співвідношення температури абсорбера й кінцевої температури теплоносія, не є постійною величиною й значно змінюється під впливом зовнішніх і внутрішніх факторів. На неї впливає інтенсивність інсоляції й витрата теплоносія. 3 ростом цих параметрів $\eta_{T}$ знижується. Існуюча залежність електричної потужності фотоелемента від витрати охолодної рідини характеризується наявністю двох виражених ділянок, які розрізняються темпом зміни функції. Перша 3 них, з невисокою інтенсивністю потоку рідини, відрізняється значним впливом функціональних параметрів, друга, при високій інтенсивності - асимптотичною стабілізацією потужності. Граничні значення переходу величини темпу зниження функції відповідають витраті рідини $0,08 \ldots 0,085$ л/( $\left.\mathrm{m}^{2} \mathrm{c}\right)$. Ці значення можуть бути прийняті для раціоналізації режиму охолодження фотобатареї. Отримано узагальнюючі залежності для визначення температури рідини на виході із пристрою й середньої температури абсорбера, які можуть бути використані для оцінки ефективності перетворення сонячної енергії в електричну й теплову енергію в завданнях режимної оптимізації.

Ключові слова: гібридний сонячний колектор, PVT-колектор, температурний режим, витрата теплоносія

V. Wysochin, V. Nikulshin, A. Denysova. Factors of the PVT-collector efficiency formation. Analytical researches of a hybrid solar collecting channel (PVT) are conducted by manufacture electric and thermal energy. The method of researches allows to analyse the following PVT-collector characteristics : a reheat temperature of an absorber and chilling liquid, as well as productivity depending on external and regime working conditions of the device. The work purpose is to work out of a method of calculation of opeating characteristics and definition of rational operating conditions of work of a hybrid solar collecting channel taking into account effective productivity. The complex mathematical model of the local analysis of processes of heat exchange and electrogeneration of a hybrid solar collecting channel for real conditions of a dynamic solar and climatic situation is used. The carried out analysis of heat exchange in alternative conditions showed that efficiency of a heat transport in a collecting channel integral cooling system $\eta_{T}$ (a relationship of temperature of an absorber and final temperature of heat-transfer agent) is not a constant and considerably changes under the external and internal factors. It is influenced by intensity of insolation and the heat-transfer agent charge. With growth of these parametres $\eta_{T}$ decreases. Existing dependence of electric power of a photo cell on the charge of a chilling liquid is characterised by presence of two expressed sections which are discriminated by rate of a variation of a function. The first of them, with low flux level of a liquid, differs considerable agency of functional parametres. The second one at high intensity differs asymptotic stabilisation of power. The limit values of the transition of the rate of decrease of the function correspond to the fluid flow rate of $0.08 \ldots 0.0851 /\left(\mathrm{m}^{2} \mathrm{~s}\right)$. These values can be accepted for rationalisation of a refrigerating duty of the photobattery. Generalized dependences for determining the temperature of the liquid at the outlet of the device and the average temperature of the absorber are obtained. These dependences can be used to evaluate the efficiency of conversion of solar energy into electrical and thermal energy in regime optimization problems.

Keywords: hybrid solar -collector, PVT-collector, temperature regime, heat-transfer agent charge

\section{Introduction}

Now are more widely used two-functional photomodules in which the problem of raise of electric and thermal energy productivity. The complex solution is gained at integration of the photovoltaic panel with the chilling device $[1-5]$.

\section{DOI: 10.15276/opu.1.63.2021.06}

(c) 2021 The Authors. This is an open access article under the CC BY license (http://creativecommons.org/licenses/by/4.0/). 
As result of it gain the hybrid device for manufacture electric and thermal energy (PVTcollecting channel). In a PVT-collecting channel photocells are chilled by means of active system of tap of warmth by the heat-transfer fluid moving in channels of a back part of the module. Thus thermal energy which in the monofunctional device goes on device heating, reducing its efficiency and lost in a circumambient, in a case with the hybrid solar module can be salvaged.

\section{The analysis of recent research and publications}

The operating temperature of the photomodule owing to features of electrogeneration should be low [4] that it is necessary to consider at sampling of regimes of maintenance of modules. A row of researches [4-7] is devoted sampling of temperature operating modes of PVT-collecting channels of devices. As a rule, researches are spent on analytical models.

Models differ in the depth of the object description. In this case, there is either a limited mathematical description (mainly in the detail of the description of objects operating in conjugate and essentially nonstationary conditions) or the narrowness of the formulated problems [4 -7]. The multifactorial nature of the choice of the operating mode of the modules and the lack of information about the regularities of the processes do not make it possible to select effective temperature modes for the operation of PVT collectors, which would take into account the thermal and electrical performance while simultaneously meeting the combined load.

\section{Purpose of the study}

Development of a method for calculating operational characteristics and determination of rational operational modes of operation of a hybrid solar collector, taking into account effective performance.

\section{Statement of the basic material}

We accept a model structure of a device containing an absorber of solar radiation, which is fenced on one side from the outer space by a transparent wall, on the other side by a flat channel with a cooling coolant.

The photovoltaic battery is characterized by the main indicator - the electric power, which depends on the solar radiation flux density, the ambient temperature and the solar energy absorber [8]:

$$
P=P_{\mathrm{SC}} k_{l . e} \frac{H}{H_{\mathrm{SC}}}\left[1+\alpha_{p}\left(t_{a b}-t_{\mathrm{SC}}\right)\right],
$$

where $P_{\mathrm{SC}}$ - battery standard horsepower under standard conditions (SC); $H$ - density of a quantity of radiant energy; $H_{\mathrm{SC}}$ - density of a stream of a solar radiation at SC; $k_{l . e}$ - factor of decrease in efficiency of the battery, $k_{l . e}=0.95 ; t_{a b}-$ absorber temperature; $t_{\mathrm{SC}}$-absorber temperature at SC; $\alpha_{P}-$ temperature factor of electric power, $\mathrm{K}^{-1}$.

Standard conditions mean the following: density of a stream of a solar radiation $H_{\mathrm{SC}}=1 \mathrm{~kW} / \mathrm{m}^{2}$, absorber temperature at the standard STC $t_{\mathrm{SC}}=25^{\circ} \mathrm{C}$.

The efficiency of heat transfer in PVT is determined by the external and internal conditions of the process. The external conditions are the intensity of the PVT irradiation and the heat exchange with the surrounding space. Internal conditions are formed during heat exchange between the absorber and the heat carrier, as well as between the heat carrier and the back wall. These processes are described by a system of energy conservation equations [4]:

- in an absorber:

$$
H(\tau \alpha)\left(1-\eta_{e p}\right)=U_{a b-a}\left(t_{a b}-t_{a}\right)+U_{a b-f}\left(t_{a b}-t_{f}\right) ;
$$

- in heat-transfer agent:

$$
\operatorname{cg} \frac{d t_{f}}{d x}=U_{a b-f}\left(t_{a b}-t_{f}\right)-U_{f-w}\left(t_{f}-t_{w}\right)
$$

- in a back wall of the channel:

$$
U_{f-w}\left(t_{f}-t_{w}\right)=U_{w-a}\left(t_{w}-t_{a}\right),
$$


where $(\tau \alpha)$ - resulted to absorb ability a heliocollecting channel; $\eta_{e p}$ - effectiveness ratio of transformation of solar energy in the electric; $U$ - surface-area factor; $g$ - heat-transfer agent mass flow rate; indexes: $a$ - circumambient; $a b$ - absorber; $f$ - liquid; $w$ - back wall.

Value $\eta_{e p}$ depends on temperature. This dependence in the field of positive temperatures can be accepted in the form of [1]:

$$
\eta_{e p}=\eta_{\operatorname{maxSC}}\left[1+\alpha_{P}\left(t_{a b}-t_{\mathrm{SC}}\right)\right],
$$

where $\eta_{\operatorname{maxSC}}$ - efficiency of the photobattery in a point of the maximum power at SC.

The system of the equations which switches on algebraic and differential equations, added with boundary conditions, characteristic for maintenance heliodevices, dared a numerical method.

The system of equations, which includes algebraic and differential equations, supplemented by boundary conditions typical for the operation of solar devices, was solved by a numerical method.

As the analysis of the distribution of the characteristic temperatures of the cooled module [4] shows, the local indicators of the thermal state of the absorber, as well as of the coolant, can differ significantly along the cooled surface. The main trend due to heat transfer is an increase in temperatures along the flow of the liquid. Such an unevenness of the temperature field in the absorber, in accordance with the above dependence, is reflected in the electric power of the element, and in the liquid flow - in the formation of the final value of the liquid temperature, which determines the demand for the generated heat.

Figure 1 shows the change in the electric power of the photocell along the flow of the coolant at different flow rates. As you can see, the power decreases as the fluid warms up at a rate that depends on the flow rate. As the flow rate increases, the power drop decreases. This circumstance makes it possible to select a cooling mode that satisfies the best electrical performance of the photocell.

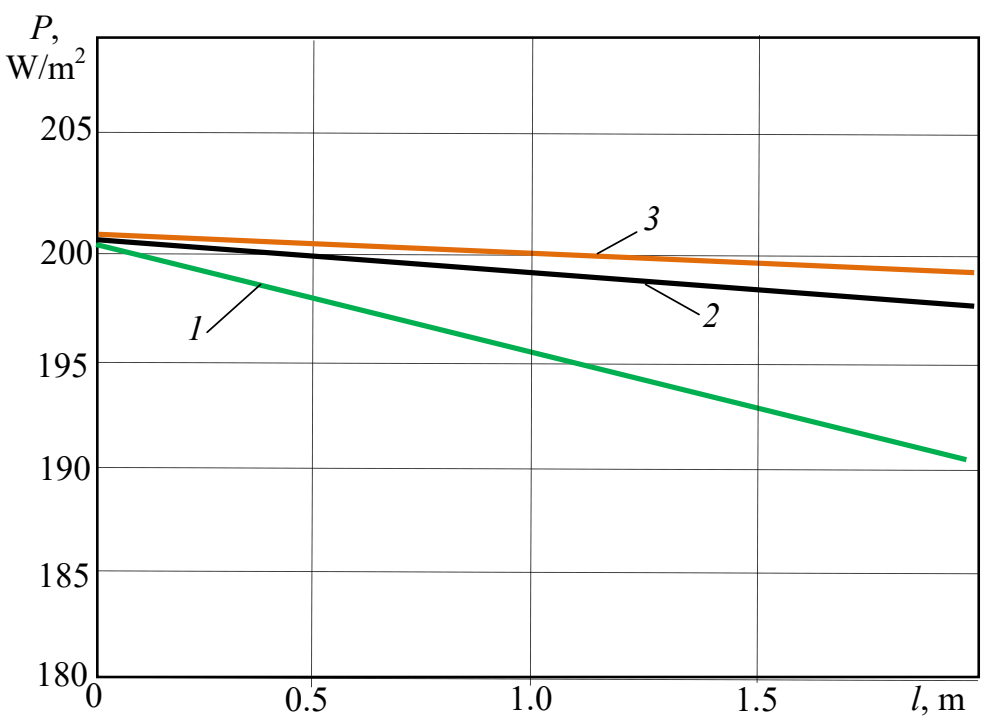

Fig. 1. Change of electric power of a photo cell along an absorber surface at different charges of a liquid. The axis direction 1 matches to a vector of speed of a stream of a chilling liquid. The liquid charge, $1 /\left(\mathrm{m}^{2} \mathrm{~s}\right)$ : $1-0.025 ; 2-0.075 ; 3-0.15$

The laws of variation of the local absorber temperature and power differ from linear. The discrepancy between the values of the characteristic indicators, found by the method of arithmetic mean and mean integral, can reach $5 \%$. Therefore, more reliable values should be determined on the basis of averaging the integral of local values along the flow - both temperature and power. This circumstance requires finding local values with a reasonable step of numerical investigation. This step was 
chosen based on the final estimate of the discrepancy in the iterative procedure for solving the system, not exceeding $0.5 \%$.

For the correct creation of a model of the processes under consideration, it is important to identify the relationship between characteristic temperatures. In [9], based on the dependence of the temperatures of the coolant and the absorber, the following relation was proposed to determine the temperature of the heated coolant:

$$
t_{f, o}=\eta_{T} t_{a b},
$$

where $\eta_{T}$ - efficiency of a heat transport, it according to [9] depends on temperature a little and it can be accepted the equal $\eta_{T}=0.9$.

\section{Results}

The analysis of heat transfer under variant conditions showed that the efficiency of heat transfer, otherwise the ratio of the temperatures of the coolant and absorber, is not a constant value and changes significantly under the influence of external and internal factors. It is influenced by the intensity of insolation and the flow rate of the coolant. With an increase in these parameters, $\eta_{T}$ decreases. The noted discrepancy within the investigated limits reached $30 \%$.

The dependence of the average power of the photocell on the specific flow rate of the coolant, shown in Fig. 2. It is characterized by a variable rate of growth of $\mathrm{P}$, and this takes place at any values of insolation. Important for optimization is the presence of a sharp change in the rate of growth of power - a break in the curves. In this area, you can fix the rational value of the flow rate. Asymptotic stabilization of the functional parameter $\mathrm{P}$, regardless of the intensity of insolation, with sufficient determination accuracy occurs at a liquid flow rate of $0.08 \ldots 0.0851 /\left(\mathrm{m}^{2} \mathrm{~s}\right)$. It is noteworthy that a flow rate close to this value is taken as optimal for solar heat production.

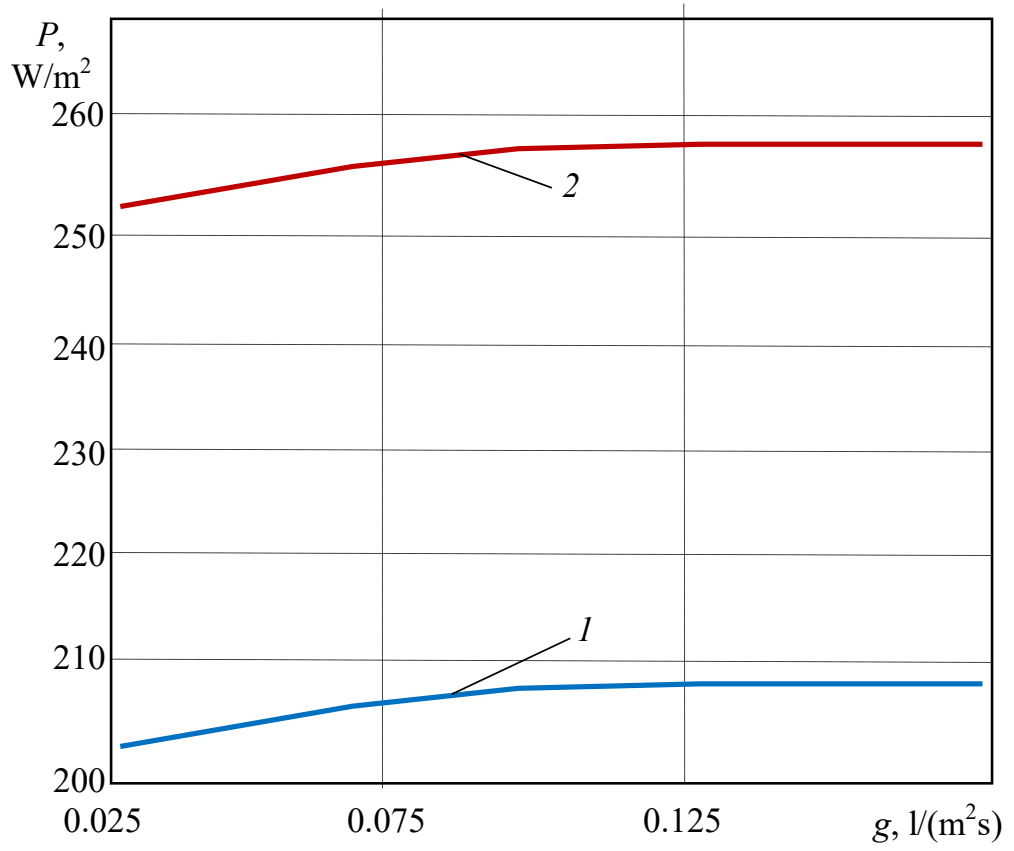

Fig. 2. Dependence of average electric power of a photocell on the charge of a chilling liquid. Power of an incoming radiation, $\mathrm{W} / \mathrm{m}^{2}: 1-800 ; 2-1000$

The efficiency of a hybrid photocell is assessed by two indicators: the developed power of power generation and the thermal potential of the coolant - the final temperature. Obviously, these two indicators have opposite (but interrelated) vectors of efficiency improvement. An increase in electrical performance with an increase in consumption is accompanied by a decrease in the heating temperature 
(Fig. 3). The latter circumstance worsens the quality of the device as a heat generator. Therefore, the search for a compromise optimum should be carried out taking into account specific priorities. If the priority is the high electrical power of the element, then the flow rate of the coolant can be taken equal to the above $-0.081 /\left(\mathrm{m}^{2} \mathrm{~s}\right)$. It is noteworthy that this consumption corresponds to a sharp change in the nature of the temperature dependence shown in Fig. 3, where the rate of decrease in the temperature curves changes to an asymptotic approximation to the minimum temperature value close to the initial one. It is obvious that this behavior of the temperature dependence determines the nature of the change in electrical power.

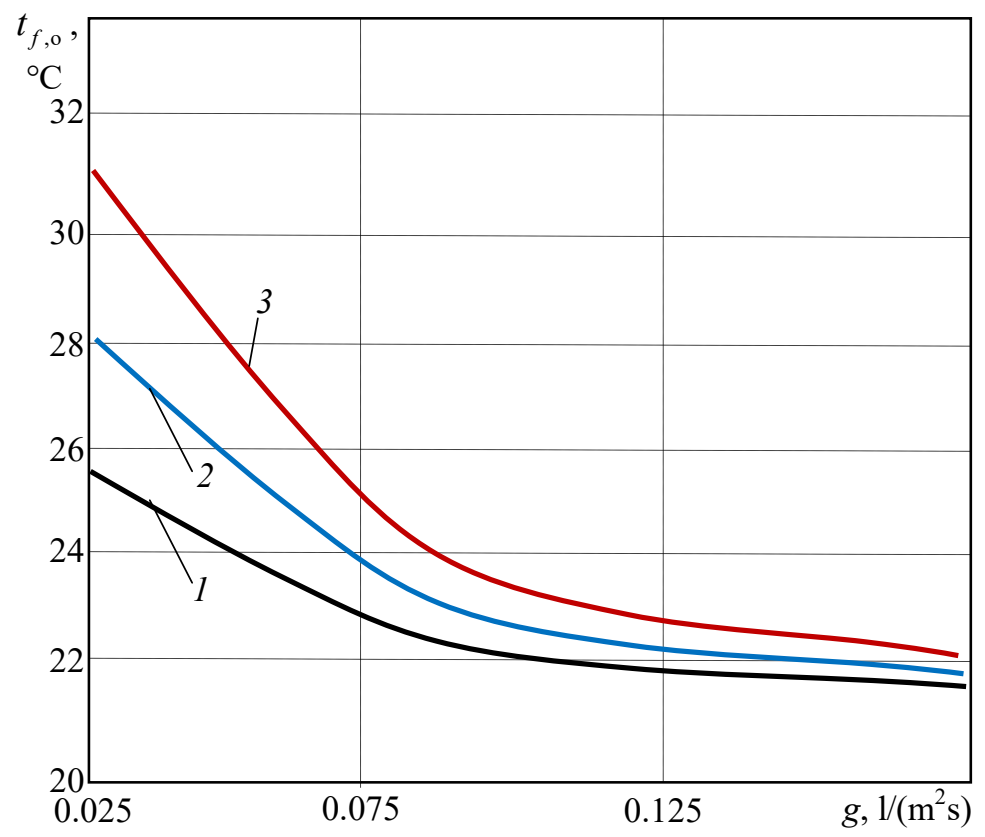

Fig. 3. Dependence of temperature of a liquid on an exit from the module from its charge and intensity of insolation, $\mathrm{W} / \mathrm{m}^{2}: 1-600 ; 2-800 ; 3-1000$

When analyzing the processes in the collector, external conditions are decisive - the outside air temperature and irradiation intensity, as well as the internal factor - the coolant flow rate. The flow rate can be selected in various ways - both constant and variable. In the general case, it can be assumed that its value is set arbitrarily and can correspond to the temperature control conditions.

For generalisation of the data of research it is convenient to express the charge of heat-transfer agent in the form of relative magnitude $k_{g}=g / g^{*}$, in which current value of parametre is led base, standard for heliocollecting channels $\left(g^{*}=0.015 \mathrm{l} / \mathrm{s}\right)$. The analysis is made at the fixed size of an absorption surface, equal $A=2 \mathrm{~m}^{2}$, that will be co-ordinated with typical sizes of the panel: width $1.0 \mathrm{~m}$, length $-2.0 \mathrm{~m}$.

Generalisation of the gained data shows that the temperature of heat-transfer agent in the end of heating can be defined in the form of the following dependence:

$$
t_{f, 0}=\left(0.039+0.205 \hat{k}_{g}\right) \ln \left(\hat{k}_{g} H\right)+\left(19.97-1.322 \hat{k}_{g}\right)+t_{a} \cdot \exp \left[\hat{k}_{g}\left(1.18+\frac{0.00275 H}{k_{g}-3.66}\right)-5.53\right],
$$

where $\hat{k}_{g}=1 / k_{g}$.

Under rational conditions of a current of a liquid the relationship takes a form:

$$
t_{f, o}=19.72+0.0775 \cdot \ln (0.188 H)+t_{a} \cdot \exp (0.00031 H-5.308) \text {. }
$$


For definition of average temperature of an absorber the dependence generalising agency of diagnostic variables at fixed, chosen as rational, the charge of a liquid is gained:

$$
\bar{t}_{a b}=22.19+0.017 H+0.072 t_{a} .
$$

This relationship can be used for definition of average electric power of a photocell. The resulted functional dependences occur at initial value of temperature of a liquid, equal $20^{\circ} \mathrm{C}$.

\section{Conclusions}

Dependence of electric power of a photovoltaic cell on the charge of a chilling liquid is characterised by presence of two expressed sections which are discriminated by rate of a variation of a function. First of them, with low flux level of a liquid, differs considerable dependence of functional parametres, second, at high intensity - asymptote power stabilisation. Boundary values of transition of magnitude of rate of decrease in function match to the liquid charge $0.08 \ldots 0.0851 /\left(\mathrm{m}^{2} \mathrm{~s}\right)$. These values can be accepted for rationalisation of a refrigerating duty of the battery. Generalising expressions for definition of temperature of a liquid on an exit from the device and average temperature of an absorber, which can be used for an estimation of efficiency of transformation of solar energy in electric and thermal energy in problems of regime optimisation are gained.

\section{Література}

1. Barbu M., Darie G., Siroux M. A Parametric study of a hybrid photovoltaic thermal (PVT) system coupled with a domestic hot water storage tank. Energies. 2020. 13. 6481. P. 38-56.

2. Гибридные солнечные коллекторы PVT. 2013. URL: http://solarsoul.com.ua/gibridnye-solnechnyekollektory.

3. Севела П., Олесен Б. Гибридный солнечный коллектор. Здания высоких технологий. 2013. № 2. C. $90-97$.

4. Харченко В.В., Никитин Б.А., Тихонов П.В., Макаров А.Э. Теплоснабжение с ипользованием фотоэлектрических модулей. Техника в сельском хозяйстве. 2013. № 5. С. 11-12.

5. Височин В.В., Нікульшин В.Р., Денисова А.Е. Особливості режимів охолодження гібридних сонячних колекторів. Енергозбереження та промислова безпека: виклики та перспективи. Наук.техн. зб.: матеріали III міжнар. наук.-пр. конф. Київ : Основа, 2020. С. 125-130.

6. Akhatov J.S. Yuldoshev I.A., Halimov A.S. Study of thermal-technical parameters and experimental investigations on PV-Thermal collector. International Journal of Engineering and Advanced Research Technology (IJEART). 2015. Volume 1. Issue 1. P. 71-75.

7. Харченко В.В., Никитин Б.А., Беленов А.Т., Тихонов П.В. Повышение эффективности энергетических установок на базе тепловых фотоэлектрических модулей. Наук. вісник НУБІП Украӥни. Серія: Техніка та енергетика АПК. 2014. № 194. Ч.3. С. 45-51.

8. Сабирзянов Т.Г., Кубкин М.В., Солдатенко В.П. Математическая модель фотобатареи как источника электрической энергии. Техніка в сільскогосподарському виробниитві. 2012. Вип.25. Ч.1. C. $331-335$.

9. Нікульшин В.Р., Височин В.В. Нетрадиційні джерела енергії: навч. посіб. Одеса : КПЦ «Білка», 2016. $208 \mathrm{c}$.

\section{References}

1. Barbu, M., Darie, G., Siroux, M. (2020). A Parametric study of a hybrid photovoltaic thermal (PVT) system coupled with a domestic hot water storage tank. Energies, 13, 6481, 38-56.

2. Hybrid solar collectors PVT. (2013). Retrieved from: http://solarsoul.com.ua/gibridnye-solnechnyekollektory.

3. Sevela, P., Olesen, B. (2013). A hybrid solar collector. Buildings of high production engineering, 2 , 90-97.

4. Harchenko, V.V., Nikitin, B.A., Tihonov, P.V., Makarov, A.A. (2013). Heat supply with using photoelectric modules. Technics in agriculture, 5, 11-12.

5. Wysochin, V.V., Nikulchin, V.R., Denysova, A.E. (2020). Features of refrigerating duties of hybrid solar collecting channels. Power conservation and industrial safety: problems and prospects. The scient. and techn. collector: mater. of the intern. scient.-pract.conf. Kyiv: Osnova, 125-130. 
6. Akhatov, J.S., Yuldoshev, I.A., Halimov, A.S. (2015). Study of thermal-technical parameters and experimental investigations on PV-Thermal collector. International Journal of Engineering and Advanced Research Technology (IJEART), 1, 1, 71-75.

7. Harchenko, V.V., Nikitin, B.A., Belenov, A.T., Tihonov, P.V. (2014). Raise of efficiency of power installations on the basis of thermal photo-electric modules. Scient. bulletin NUBIP України. A series: Techn. and power engin. AIC, 194, 3, 45-51.

8. Sabirzjanov, T.G., Kubkin, M.V., Soldatenko, V.P. (2012). Mathematical model of the photobattery as source of electric energy. Technics in farming industry, 25, 1, 331-335.

9. Nikulchin, V.R., Wysochin, V.V. (2016). Nonconventional energy sources: the manual. Odessa: KPC «Belka».

Височин Віктор Васильович; Wysochin Victor, ORCID: http://orcid.org/0000-0003-2279-203X

Нікульшин Володимир Русланович; Nikulshin Vladimir, ORCID: http://orcid.org/0000-0001-5946-8562

Денисова Алла Євсї̈вна; Denysova Alla, ORCID: http://orcid.org/0000-0002-3906-3960

Received Februrary 05, 2021

Accepted March 23, 2021 